\title{
Inculcating Multicultural Education Through the Development of Religious Culture in Junior High School (SMP) Negeri 7 Mataram
}

\author{
Maimun* \\ UIN Mataram \\ Jl. Gajah Mada No. 100, Kota Mataram, Nusa Tenggara Barat. 83116
}

\begin{tabular}{l|l|l} 
Submitted: 17th June 2020 & Revised: 20th June 2020 & Accepted: 20th July 2020
\end{tabular}

\begin{abstract}
Multicultural education can be used as a media for the development of equal human potential, able to respect each other's differences in terms of religion, tribe, race, ethnicity, culture, and language. This study focuses on: (1) How is the concept of multicultural education through the development of religious culture in SMP Negeri 7 Mataram ?; and (2) What is the reality of multicultural education and religious culture developed in SMP Negeri 7 Mataram? This type of research is descriptive qualitative, describing the concepts and reality of the implementation of multicultural education with the development of religious culture. The results of this study are (1) The concept of Multicultural Education with the development of religious culture adapted to the vision, mission, and profile of the school that is building religious attitudes and behaviors that are reflected through cooperation, tolerance and culture in the community of school members by not ignoring religious concepts that embraced by each school citizen; and (2) The reality of multicultural education with the development of religious culture is reflected in the religious and social values or norms of the activities of all school members, and the availability of adequate places of worship for students who are implementing religious programs for all religious adherents.
\end{abstract}

Keywords: Multiculturalism, Education, Religious, Culture

\section{INTRODUCTION}

Education is part of the primary needs that cannot be separated from human life. It also has a social function and plays a very important role because it can build human character and personality that is useful for survival in the midst of society (Stokke, \& Lybæk, 2018; Mahfud, 2018). That is why it is called long life education because humans cannot be separated from the process of education and learning (Kurniawan, 2018; Harjatanaya, \& Hoon, 2018). 
It is stated that education functions to develop capabilities and build the dignified character and civilization of the nation which aims to develop the potential of students in order to be human beings who have faith and piety to God Almighty, noble, healthy, knowledgeable, capable, creative, independent, and become democratic and responsible citizens (Law on National Education System, 2003). The function of education in the Law of National Education System is also directed at developing the potential of students as equal subjects, mutual respect for each other, which is in formal terms it is called education that adheres to the multicultural paradigm (Childs, 2017; Selenica, 2018).

Educational experts and observers have talked a lot about multicultural education as a very important tool in the nuances of cultural differences brought by students including religious, ethnic, linguistic and cultural differences. According to Fuad Fanani (2004) that the main element in multicultural education is the placement of students' positions as equal subjects. There is no superiority in one student's cultural component to other students. So this multicultural education can train and build students' charactersto be able to democratic, humanist and pluralist in their environment. Because the basic values of this education are the building and developing the values of tolerance, empathy, sympathy and social solidarity (Lasijan, 2014: 132)

In the context of education in Indonesia, multicultural education is closely related as a process of developing self-potential that is able to respect diversity. Being respect tothe differences in terms of culture, tribe, race, ethnicity, sect, and religion. Azyumardi Azra (2003) explains that multicultural education as education for all that gives serious attention to the development of tolerance, respect for ethnic, cultural and religious differences, and provides civil rights including minority groups (Rosyada, 2014; Walter, 2018; Ben-Peretz, \& Flores, 2018).

As a starting point in describing the importance of multicultural education, there are several results of previous studies. For example, research conducted by Mulkul Faris Nalva that multicultural education is a way to foster an attitude of tolerance in every human being for all differences in terms of race, tribe, culture, ethnicity, religion, and the like, through the inculcation of small practices that are instilled early on in every formal or non-formal education process (Kuni and Mulkul, 2019: 221). Furthermore, the results of Kaprama Sangadji's research that multicultural education becomes an alternative means of resolving social and cultural conflicts include: race, tribe, class, social, economic, gender, disability, age difference, and language (Sangadji, 2016: 45) . 
In the context of Indonesian education, the multicultural paradigm is actually embedded in curricula and subjects, especially those that touch on everyday life with the label of courtesy, mutual respect, cooperation, mutual assistance, and mutual acceptance (Chan, \& Band, 2018). All labels are packaged in Civics and Religious materials. In religious content, for example, all material content taught focus on how to build harmonious human relations, so educational institutions have a moral responsibility to develop them in students' social behavior (Harjatanaya, \& Hoon, 2018).

Based on the preliminary observations of researcher, the development of multicultural education and religious culture in SMP Negeri 7 Mataram seems to develop well, from the heterogeneity of culture, religion, social, and environmental background seems to have been managed well, so that the alignment of students in socializing with their fellows is felt strongly supported by the application of religious culture in the school environment. The students are polite, friendly and religious activities of all religions are well implemented (Wibowo, \& Wahono, 2017; Parker, 2017). Likewise, the commemoration of religions' feast days is implemented safely and in high tolerance. In addition to religious backgrounds, heterogeneity from family life backgrounds such as students from BTN housing, settlement and villages get along in a peaceful and safe atmosphere (An'Amta, \& Mattiro, 2017; Bin-Tahir, Bugis, \& Tasiana, 2017).

The condition cannot be separated from the roles of school who has efforts in developing multicultural education through religious culture, as a result of interview conducted by the researcher to some of teachers in SMP Negeri 7 Mataram, the development of multicultural education and religious culture in the school is begun from the implementation of religious and moral values and tolerance between students.

The conditions described above encouragethe researcher to learn how SMP Negeri 7 Mataram inculcating multicultural education through the development of religious culture in the midst of heterogeneity of school members, both within the community of edicated student and education staff.

Based on the background above, researcher focused on: "How to inculcate multicultural education through the development of religious culture." The focus is described in the following sub focus: (1) How is the concept of multicultural education through the development of religious culture in SMP Negeri 7 Mataram ?; and (2) What is the reality of multicultural education and religious culture developed in SMP Negeri 7 Mataram. 


\section{METHODS}

This research used a qualitative approach. According to Ghony, qualitative research aims to describe, analyze phenomena, events, social activities, attitudes, beliefs, and perceptions and thoughts of individuals or groups (Ghony and Fauzan, 2014: 89). This type of research is a descriptive analysis, which describes the findings related to the application of multicultural education with the nuances of religious culture by using natural setting. There are two types of data, namely primary and secondary. Primary data obtained in the form of words or verbal speech (verbal) and behavior of the subject (informant), namely; (a) Principal of SMP Negeri 7 Mataram; (b) Representative of Student Affairs; (c) Teacher; (d) Administrative Staff; and (e) Students who relate to the phenomena and events, or religious social activities, social behavior and attitudes, tolerance and mutual respect. Determination of informants is conducted through two steps. First, it is used purposive sampling technique. Second, it is used snowball sampling technique (Sugiyono, 2008: 300). This snowball technique is stopped if the data obtained related to the values of multicultural education through the development of religious culture in school members is the same as the data that was obtained previously (point of theoretical saturation).

There are three techniques in data collection: (1) in-depth interviews: this technique is used to obtain emic data, that is the data relating to the implementation of multicultural values in school members; (2) nonparticipant observation, and (3) documentation study. The analysis procedure uses an interactive model according to Miles and Huberman, namely: (l) data reduction, i.e. classifying data, as well as discarding incompatible data, and organizing data; (2) data presentation, namely: finding meaningful forms and patterns of relationships and providing conclusions; and (3) drawing conclusions. The criteria for checking the validity of data using naturalistic as Lincoln and Guba explain that the implementation of checking the validity of the data is based on four criteria, namely the degree of trust (credibility), transferability, dependability and confirmability (Lincoln and Guba, 1985: 301)

\section{RESULT AND DISCUSSION}

Organizing resources that are effective, democratic, and student-friendly in creating a school atmosphere with a multicultural paradigm and religious culture, heterogeneity of SMP Negeri 7 in terms of beliefs and religions, tribe, ethnicity, and language is the tasks and responsibilities of school membersthat have to be created. As Mu'arif (2008) explains, the educational paradigm with a multicultural perspective is actually begun 
from awareness; that every human being has different potential. It means that every human being has different potential (ability), so the education process must be implemented by using the principle of wisdom. Do not let every potential possessed by students be ignored (Yulianto, 2020). The following are research findings related to the concept and reality of the application of multicultural education through the development of religious culture in SMP Negeri 7 Mataram.

\section{The concept of multicultural education through the development of religious culture in SMP Negeri 7 Mataram}

The concept of multicultural education and the development of religious culture that is inculcated in SMP Negeri 7 Mataram refer to the vision and mission agreed upon by all school members. Based on the concept of vision and mission, the principal and school members develop the concepts of multicultural education and religious culture.

An important point that is interpreted as the concept of multicultural education and religious culture in SMP Negeri 7 Mataram is how to create a character of school members; have religious attitudes and behaviors that are reflected through cooperation, respecting each other, caring, honestly, good personalities and polite. The concept of multicultural education and religious culture also can be seen from the tolerance among school members, as we know that SMP Negeri 7 Mataram is very heterogeneous in belief and faith.

James Banks explains that multicultural education has five interrelated dimensions that can assist teachers in implementing several programs that are able to respond the students' differences, they are: (a) Dimension of content integration. This dimension is used by teachers to provide information with "key points" of learning by reflecting the different materials. In particular, teachers combine the content of learning material into the curriculum with a variety of perspectives. One of common approaches is to acknowledge its contribution; teachers work based on their curriculum by giving limitation to the fact about the heroic spirit of various groups. In addition, the learning design and unit are not changed unlesstheir approach, the teacher adds several units or topics specifically related to multicultural material; (b) The dimension of knowledge construction. A dimension where teachers help students to understand multiple perspectives and formulate conclusions which are influenced by the discipline of knowledge that they have. This dimension also relates to students' understanding of the changes in knowledge; (c) Dimension of prejudice reduction. 
The teacher conducts efforts to help students in developing positive behavior towardthe differences of group. For example, when the studentsbring negative behaviors and have misconceptions about different races or ethnicities and other ethnics to school, education can help students to develop more positive intergroup behaviors, provision of established and certain conditions. The two intended conditions are learning materials that have positive images about group differences and the use of those learning materials consistently and continuously. Research shows that the use of multicultural textbooks or other teaching materials and cooperative learning strategies can help students to develop positive perceptions toward the differencesof race. This type of strategy and materials can produce choices for students to be friendlier to other races, ethnicities and cultural groups; (d) Equitable pedagogy. This dimension pays attention to ways in changing learning facilities, so it can increase the achievement of students in learning for a number of students from various groups. Learning strategies and activities that can be used as efforts to treat education fairly, they are in term of cooperative learning not competitive learning.

This dimension also concerns education that is designed to build the school environment into many types of groups, including groups of ethnic, women, and students with special needs who will provide educational experience in terms of equal rights and learning opportunities; and (e) The dimensions of empowering school culture and social structure. This dimension is important in empowering the culture of students brought to school from different groups. In addition, it can be used to develop social structures (schools) that utilize the diverse cultural potential of students as characteristics of local school structures, for example relating to group practice, social climate, exercises, extracurricular participation and staff rewards in responding to the differences in school environment (Ibrahim, 2013: 143-144).

The five dimensions of multicultural education above are in accordance to the nuances of education in Indonesia, the school just adapts to the suitable conditions to be developed. In fact, the concept of multicultural education and religious culture developed in SMP Negeri 7 Mataram direct all parties in the school to be based on the basis of tolerance and religion so that the created conditions are related to students' attitudes and behaviors, such as caring for others as one of developed schools' concept so that mutual help will always be seen in religious and ethnic heterogeneity among school members.

Fay (1996) said thatthe relevant concepts to multiculturalism are democracy, justice and law, cultural values and ethos, togetherness in 
equal differences, ethnicity, culture, religious beliefs, cultural expressions, private and public domains, human right, community cultural rights, and other relevant concepts (Ibrahim, 2013: 134).

The findings of this research at the level of this concept are that the launching of greeting culture by all elements of schools based on their religion and belief, big day committee for all religions that are maximally supported by the school. That is the concept of Multicultural and religious culture that was proposed by the school and it applies to all school members regardless the differences of religious, tribe, ethnic and culture. As Azyumardi Azra said, it is not something that is taken for granted but must be pursued through a multiculturalist educational process, that is education for alland education that gives serious attention to the development of tolerance, respect to the differences of ethnic, culture, and religious, and also gives the civil rights to the minority groups (Rosyada, 2014: 3-4).

One of the forms of multicultural concept and religious culture implementation launched by the School is the harmony in the association between school members who have different religions, ethnicities and cultures. By using the concept to build harmony,the school life in heterogeneity will be able to live side by side safely and comfortably.

This is in line with Sonia Nieto (2002) that multicultural education is a comprehensive and fundamental educational process for all students. This type of education opposes all forms of racism and discriminations in the schools and society by accepting and affirming a plurality that is reflected among students, their communities and teachers. According to Sonia, multicultural education must be embedded in the curriculum and teaching strategies, including every interaction conducted between teachers, students, families and the overall teaching and learning atmospheres. This type of education is a critical pedagogy, reflective and becomes the basis of action for change in society, so multicultural education develops democratic principles in social justice (Andaryuni, 2014: 57).

Based on the experts, the concept of multicultural education and the development of religious culture in SMP Negeri 7 Mataram is very consistent with the profile of the school, which is an outstanding, cultured and religious. This means that in addition to academic achievement being a competitive program in guarding the educational process, mutual respect, cooperation and tolerance become a culture in the association of school members by not ignoring the religious concepts adopted by them. This is in line with Quraish Shihab (1998) explains that in order to strengthen the nationalism although different religion, Al- 
Qur'an underlines for the first time that difference is the law of life. Besides, the difference is the will of God and also for the preservation of life, as well as to achieve the goals of life on earth (Asrul Anam, 2020: 19)

\section{The reality of multicultural education and religious culture developed in SMP Negeri 7 Mataram}

Religious culture in school is a starting point in the application of multicultural education with values in all school activities such as mindset, behavior, traditions, habits, which are practiced by all school members both students, teachers, principals, and education staff. The application of multicultural education and the inculcation of religious culture in SMPN 7 Mataram is very urgent because the heterogeneity and plurality of religion, tribe, ethnic, culture and language, for example, Hindus students are the second largest number after moslems, then Christians, Khonghucu, and Buddhism. Besides, in terms of ethnic, such as Bali, Sasak, Chinese, Mbojo, and Samawa, this diversity actually becomes multicultural as a paradigm in implementing educational process.

Religious values or norms become an important point to be used as a reference or a common guideline in school. It is in line with Muhaimin in his book; Reconstruction of Islamic Education, explains that the strategy of developing religious culture in school borrows the theory of Koentjaraningrat (1974) about the form of culture, the existence of efforts in developing three levels, they are level of adopted values, level of habitual action, and cultural symbols.

The level of adopted valuesneeds to be formulated with the agreed religious values that need to be developed in the School. Furthermore, it need to build commitment and loyalty among all school members towards the agreed values. For example, the relationship between people or school members with God (vertical relationship) and relationship between people or school members with other (horizontal relationship), and their relationship with their environment.

The level of habitual action, the agreed religious values are manifested in the form of daily attitudes and behavior by school members. The development process can be conducted in three ways; first, the socialization of agreed religious values as ideal attitudes and behaviors to be achieved in the future at school. Second, the determination of weekly or monthly action plans as prisoners and systematic steps that will be conducted by all school members in implementing the agreed religious values. Third, giving awards to the achievements of the school members, such as teachers, education staff, and students as habit formation that 
honor the attitudes and behaviors of commitment and also loyalty to the agreed teachings and religious values.

Level of cultural symbols. The development that needs to be conducted is that to replace unsuitable cultural symbols with the suitable ones. The changes of symbols can be conducted by changing the model of dress in term of covering the aurat, displaying students' work, photographs and motto that have messages of religious values and the like (Muhaimin, 2009: 326).

The construction of values and culture above is in line with what has been applied in SMP Negeri 7 Mataram that the agreed values become a guideline in creating an atmosphere of life for school members, both between the principal and teachers, between teachers and teachers, teachers and students and between students and other students.

According to the observation that has been conducted by researcher, these values are sufficient to color the activities of all components in SMPN 7 Mataram. For example,tolerance values. All components in this school have mutual respect although they have difference beliefs. The atmosphereof Ramadan can be felt. Teachers, employees and Moslem students were fasting quietly and peacefully. The sound of holy AlQur'anin the school mosque, where Muslim students read and study AlQur'an with the guidance of the teacher, is like the sound of bees. For non-Muslim students who show respect and care by not conducting activities (eating and drinking in any places) that can disrupt the fasting of their friends. Even when breaking the fast together, all school members of all religions are actively involved by giving contributions that have been agreed by all school members.

In the midst the heterogeneity and religious plurality that colored the lives of the school members of SMPN 7 Mataram, tolerance values seemed to be applied by school members. The researcher gains the data that shows that the tolerant atmosphere in SMPN 7 Mataram was build because each of school members had fully understood the agreed religious values as a reference or guideline.

The implemented religious values in the creation of an atmosphere or culture are in line with multicultural activities. In the context of this study, religious activity is interpreted as an effort to cultivate positive behavior based on values that are guided and can be observed in real life. In other words, religious activity is an effort to translate and realize the values contained by multicultural education in real life. This can be conducted through a variety of activities;they are building a sense of secure, managing order, providing role models and openness. 
Nurdin, the idea of multicultural in Islamic education is not something new and difficult because there are at least three reasons for that; first, Islam teaches to respect and recognize the existence of others.Second, the concept of Islamic brotherhood is not limited.Third, according to Islam, a noble person is the most pious person (Lasijan, 2014: 135).

Multicultural education and religious culture in SMPN 7 Mataram are developed through securitity, orders, role models and openness. A safe and peaceful school atmosphere can motivate school members to do all activities well. Without a sense of security, all educational activities include the increase of faith and piety of students will not going well.

The sense of secure that occurs in SMPN 7 Mataram is created through structuring the school situation, for example,assigning people basedon their competence without looking at their religious, culture, or ethnic backgrounds. The portion of religious activities is given the same space and time to all religious adherents in celebrating their big day. This is intended to anticipate the inconvenience of relations between school members.

An orderly culture can be clearly seenin SMPN 7 Mataram. All school members aware that the order is a reflection of harmony and wellordered in relationship among school members. This order is implemented in the use and maintenance of school facilities and infrastructure, the use of learning time and the relation to the surrounding society. This culture is an initiative that was built by all school members. It wasbegun from the smallest environment, such as classrooms, library, office, and bathroom or toilet, and then developed into the back and front yard of the school.

Furthermore, the establishment of tolerance in students is related to the implemented religious symbols in the form of the availability of adequate places of worship for students who conducted religious programs for all students of all religions. In the school environment, there is a mosque that is quite large and majestic as a center of worship for Moslem students. For Christian and Buddhist students, each room is relatively adequate. Meanwhile, the implementation of religious programs for Hindus took place in a temple outside the school environment. This is clear evidence of the active participation of society in the success of the school programs. Another form of religious symbols in this school is that all school members are required to wear clothing that covers the aurat, both male and female. Even female Moslem students are required to wear hijab. 
One's religious diversity can be manifested in various aspects of life. Religious activities not only occur when a person performs ritual behavior (worship), but also when they conducted other activities that are empowered by supernatural powers. Not only related to the activities that are visible, but also theunvisible one and occur within one's heart (Ancok, 2005: 76).

The various research findings above are clearly visible, the efforts that have been conducted by all members of the school in implementing the creation of multicultural and religious culture atmospheres. These efforts include: (1) Establishing values that serve as a reference in behaving in school; (2) Performing various activities; and (3) Providing adequate places of worship for the implementation of religious programs. The whole implementation of the creation of religious culture is that to build the tolerance of students, both in the school environment, family and society.

In addition, building human relations in the midst of religious, ethnic, culture and linguistic heterogeneity is the concept chosen by the School in the implementation of multicultural education and religious culture. This becomes a paradigm because if there are mutual understanding and trust have been culcated in themselves, then good relations will be appeared between them even though different beliefs, religion, culture, and language. According to the observations of researcher,the key of implementation of multicultural education and the development of religious culture is polite behavior, mutual assistance, polite communication and kinship among school members even in different religions, ethnicities, cultures and languages.

Bikhu Parekh said, "an education in freedom, both in the sense of freedom from ethnocentric prejudices and beases, and freedom to explore and learn from other cultures and perspectives (Andaryuni, 2014: 57).

Good relationships that are built among the school members in the form of intimacy between superiors and juniors, juniors with juniors, students and teachers, students and students look harmonious. The school principal has the initiative to be at the forefront in social humanitarian relations.

\section{CONCLUSION}

The concept of Multicultural Education and the development of religious culture in SMP Negeri 7 Mataram can be seen from the program launched by the School in accordance to the vision, mission, and profile of the school, they are: (1) Building character, that is, having religious attitudes and behaviors that are reflected through cooperation and tolerance, and 
also become a culture in the association of school members by not ignoring the religious concepts each of school member; (2) Trainingthe school members to have good attitudes and behaviors, caring, and polite in speaking and behaving; (3) Encouraging school members to care for others that is developed through the mutual help in heterogeneity of religious, ethnic, culture and language; and (4) Inculcating greetings habit to students by saying good morning to their teachers and coming guests.

The reality of implemented multicultural education and the development of religious culture in SMP Negeri 7 Mataram is reflected in: (1) Religious and social values or norms that characterize the activities of all school members; (2) the value of tolerance, mutual respect among the believers; (3) The appearance of a sense of secure for all school members. Security is the main point in creating harmonious and pleasant atmospheres in school; (4) An orderly culture can be clearly seenin the environment of SMPN 7 Mataram. All school members are aware that order is a reflection of harmony and well-orderedamong school members; and (5) Availability of adequate places of worship for students who conducted religious programs of all adherents.

\section{REFERENCES}

Ahnaf, M. I. (2018). Socio-Ethical Origin of Multiculturalism in Indonesia. Multiculturalism in Asia-Peace and Harmony, 126.

An'Amta, D. A. A., \& Mattiro, S. (2017, November). Development of Democracy in Multiculturalism Through Open Spaces in Indonesia. In 1st International Conference on Social Sciences Education-" Multicultural Transformation in Education, Social Sciences and Wetland Environment" (ICSSE 2017). Atlantis Press.

Ancok, D., Suroso, F. N., \& Ardani, M. S. (2000). Psikologi islami: Solusi islam atas problem-problem psikologi. Yogyakarta: Pustaka Pelajar.

Andaryuni, L. (2014). Pendidikan Multikultural Di Perguruan Tinggi (Studi Terhadap STAIN SAMARINDA). Jurnal Fenomena, 6(1).

Ben-Peretz, M., \& Flores, M. A. (2018). Tensions and paradoxes in teaching: implications for teacher education. European Journal of Teacher Education, 41(2), 202-213.

Bin-Tahir, S. Z., Bugis, R., \& Tasiana, R. (2017). Intercultural Communication of a Multicultural Family in Buru Regency. Lingual: Journal of Language and Culture, 9(2), 8. 
Chan, C. D., Cor, D. N., \& Band, M. P. (2018). Privilege and oppression in counselor education: An intersectionality framework. Journal of Multicultural Counseling and Development, 46(1), 58-73.

Childs, K. (2017). Integrating multiculturalism in education for the 2020 classroom. Journal for Multicultural Education.

Ghony, M. D., \& Almanshur, F. (2012). Metodologi penelitian kualitatif. Jogjakarta: Ar-Ruzz Media.

Harjatanaya, T. Y., \& Hoon, C. Y. (2018). Politics of multicultural education in Post-Suharto Indonesia: A study of the Chinese minority. Compare: a journal of comparative and international education.

Hoon, C. Y. (2017). Putting religion into multiculturalism: Conceptualising religious multiculturalism in Indonesia. Asian Studies Review, 41(3), 476-493.

Ibrahim, R. (2015). Pendidikan Multikultural: Pengertian, Prinsip, dan Relevansinya dengan Tujuan Pendidikan Islam. Addin, 7(1).

Kaprama, S. (2016). Pendidikan Multikulturalisme dalam Pengembangan Kurikulum Perguruan Tinggi. Biology Science and Educational, 5 (1), 113-126

Kuni \& Mulkul. (2019). Pendidikan Multikulturalisme sebagai Strategi Radikalisme. Dinamika Penelitian: Media Komunikasi Sosial Keagamaan. 19(2). 51-64

Kurniawan, J. A. (2018). When Human Rights Are Not Enough: A Failure of Multiculturalism in Indonesia:(A Preliminary Hypothesis). JSEAHR, 2, 236.

Mahfud, C. (2018). Chinese Muslim Community Development in Contemporary Indonesia: Experiences of PITI in East Java. Studia Islamika, 25(3), 471-502.

Muhaimin. (2009). Rekontruksi Pendidikan Islam; Dari Paradigma Pengembangan, Manajemen Kelembagaan, Kurikulum hingga Strategi Pembelajaran (cet. I). Jakarta: PT Raja Grafindo.

Parker, L. (2017). Intersections of Gender/Sex, Multiculturalism and Religion: Young Muslim Minority Women in Contemporary Bali. Asian Studies Review, 41(3), 441-458. 
Rosyada, D. (2014). Pendidikan multikultural di Indonesia sebuah pandangan konsepsional. SOSIO-DIDAKTIKA: Social Science Education Journal, 1(1), 1-12.

Selenica, E. (2018). Education for whom? Engineering multiculturalism and liberal peace in post-conflict Kosovo. Southeast European and Black Sea Studies, 18(2), 239-259.

Stokke, C., \& Lybæk, L. (2018). Combining intercultural dialogue and critical multiculturalism. Ethnicities, 18(1), 70-85.

Sugiyono. (2008). Metode Penelitian Kuantitatif Kualitatif dan RED. Bandung: Alfabeta.

Walter, J. S. (2018). Global perspectives: Making the shift from multiculturalism to culturally responsive teaching. General Music Today, 31(2), 24-28.

Wibowo, A. P., \& Wahono, M. (2017). Pendidikan Kewarganegaraan: usaha konkret memperkuat multikulturalisme di Indonesia. Jurnal Civics: Media Kajian Kewarganegaraan, 14(2), 196-205.

Yulianto, A. (2016). Pendidikan Ramah Anak Studi Kasus SDIT Nur Hidayah Surakarta. At-Tarbawi: Jurnal Kajian Kependidikan Islam, 1(2), 137-156. 